The abolition of child labor is one of the four categories of rights adopted in 1998 by the

\title{
CHILD LABOR AND HEALTH: A SYSTEMATIC REVIEW
}

International Labor Declaration (ILO) Declaration on Fundamental Principles and Rights at Work (Convention 2005; International Labour Office 2017). Although member states are committed to respect and promote these rights, even if they have not ratified the relevant conventions, hundreds of millions of children worldwide are still involved in various types of labor (Council 2016; Office 2011). In addition, ending child labor in all its forms by 2025 is one of the targets of Sustainable Development Goal 8, to "promote sustained, inclusive and sustainable economic growth, full and productive employment and decent work for all"(Boothe 2016).

Children are known to be especially vulnerable to both harmful workplace exposures (ergonomic, chemical exposure hazards) and injuries (Fassa et al. 2000). In addition, labor imposes physical and mental strain, which the working child is likely ill-equipped to handle - the increased caloric requirements for strenuous labor, for example, may cause malnourishment to a child. These stresses and the loss of developmental opportunities could adversely impact children into adulthood and over the life-course (Cigno and Rosati 2005). Finally, time spent working severely constrains learning and playing time (Nishijima et al. 2015; Shendell et al. 2016).

However, it may be argued that work also has some positive effects on the working child. Working children might learn adaptation strategies that increase their resilience, which can help them cope better with adverse situations (Blair 1992). The skills they acquire in the work place may also give them an advantage over non-working children in later life. Additionally, the income from a working child may improve his or her nutritional status and overall health, and 
23 may confer health benefits to other family members as well (Genicot 2005). Finally, work and

24 schooling are not mutually exclusive. Some policies allow certain types and quantities of work

25 (Center 2017). Therefore, there is a lack of clarity in the overall relation between child labor and 26 health.

27 Considering that child labor is more prevalent in developing countries(Council 2016) and 28 that an expected health dividend from the elimination of child work is one of the major drivers of 29 international efforts to intervene at the policy level, there is the need for a clearer understanding 30 of how child work relates to health. This review synthesizes the available knowledge from the 31 past two decades of research into the relationship between child labor and health in low- and 32 middle-income countries (LMICs), identifies unexplored areas and discusses general limits of 33 published evidence. The selected health outcomes are injuries (work-related and otherwise), 34 nutritional outcomes (anemia, wasting and stunting) and conditions due to workplace toxic 35 exposures (including exposure to loud noise, dust, extreme cold or heat, chemical, biological and 36 radiation exposures). These outcomes are most commonly hypothesized to be the immediate 37 (injuries and harmful exposures), and the long-term effects (nutritional status) of child labor 38 (Parker 1997).

\section{METHODS}

42 The study protocol was registered in PROSPERO and it is available at 43 (http://www.crd.york.ac.uk/PROSPERO/display_record.asp?ID=CRD42016041317). We 44 completed a systematic review following a registered protocol and PRISMA guidelines 45 (appendix 1) (Moher et al. 2009). The search strategy was designed with the help of a 
46 professional librarian to favour sensitivity over specificity in an effort to be as comprehensive as

47 possible (appendix 2). Four indexing and abstracting services (EMBASE, MEDLINE, Scopus, 48 and ISI Web of Science) were searched in November 2017. All articles, without restrictions on 49 language, were considered for inclusion. Manual searches for additional eligible studies were 50 performed by reviewing the reference lists of included studies. Figure 1 summarizes our 51 literature search.

52 The population of interest for this review was all children under 18 years in LMICs, classified 53 according to the World Bank Data Catalogue (WorldBank 2016).

54 The exposure was child labor, defined as paid or unpaid economic activity by children 55 under 18 years of age either for family or outside the home (ILO 2011). The outcomes included 56 were: injuries, nutritional outcomes (e.g. anemia, malnutrition, wasting, stunting, weight-for 57 height), and harmful workplace exposures (e.g. chemical toxins, excessive heat/cold, physical 58 risks such as working with heavy machinery without adequate protective measures). We 59 included studies published since January 1996 that (1) described the incidence or prevalence of 60 these outcomes among working children or (2) examined the association between child labor and 61 these outcomes by including an unexposed control group. Studies were excluded if entirely 62 qualitative, or if they only examined the prevalence of child work.

\section{Data Extraction}

Two investigators (BLBK and OO) independently reviewed titles and abstracts and applied the inclusion and exclusion criteria to select studies for full-text review. Discrepancies were resolved by consensus between all research collaborators. The following information was extracted for each study included during the full-text review: reference, country of study, study 
70 child work studied), outcome (including details of units of measurement), covariates adjusted

71 for, effect measures for each outcome as reported (captured separately for each outcome of

72 interest), and subgroup analyses. Study quality was assessed using the Newcastle-Ottawa Scale

73 which provides a quantitative measure of study quality based on study characteristics (Wells et 74 al. 2011).

75

76

77

78

79

80

81

82

83

84

85

\section{RESULTS}

A total of 1090 citations were initially identified by the search strategy. Among the 153 articles selected for full text review, 64 satisfied our inclusion criteria. An additional 14 articles were added after reviewing the references of included articles. In total, 78 articles were extracted (Figure 1).

Most studies were conducted in Asia and South America, with a fifth coming from India alone. 74 studies were conducted in individual countries (Figure 2) and four studies included more than one country. 38\% of studies estimated the prevalence of at least one of the health outcomes (Amiri et al. 2014; Ansari et al. 2015; Ayelo et al. 2013; Baig et al. 2005; Banerjee et al. 2008; Baron 2005; Beegle et al. 2009; Caglayan et al. 2010; Chandrashree 2014; Dalal et al. 2016; DM Satpathy 2005; El-Gilany et al. 2007; Elci et al. 2007; Gol 2016; Hawamdeh and Spencer 2003a; Hawamdeh and Spencer 2003b; Hawamdeh et al. 2001; Javed et al. 2013; Kana et al. 2010; Khan et al. 2007; Miquilin Ide et al. 2015; Nicolella et al. 2008;

Oviedo-Trespalacios et al. 2013; Pinzon-Rondon et al. 2009; Roggero et al. 2007; Saha and Sadhu 2014; Tiwari et al. 2004; Vasconcelos et al. 2010; Zainab and Kadir ; Zaki et al. 
92 1998), $42 \%$ had at least one control group of non-working childrenand examined the association

93 between child work and health (Ahmed and Ray 2014; Ambadekar et al. 1999; Athanasiadou

94 et al. 2008; Awan et al. 2010; Basema et al. 2003; Bose-O' Reilly et al. 2008; Cortez et al.

95 2007; Cuadra et al. 2007a; Cuadra et al. 2007b; Cuadra et al. 2009; Cuadra et al. 2006;

96 Daga 2000; Das et al. 2011; Das et al. 2013; Doocy et al. 2007; Duyar and Ozener 2005;

$97 \quad$ Etiler et al. 2011; Fassa et al. 2005; Furman and Laleli 2000; Graves et al. 2014;

98 Hawamdeh and Spencer 2002; Hincapie 2007; Joshi et al. 1996; Junaid et al. 2017; Laraqui

99 et al. 2000; Nuwayhid et al. 2005; Omokhodion and Omokhodion 2004; Saddik et al. 2005;

Singhal et al. 2006; Sughis et al. 2012; Sughis et al. 2014; Tiwari 2013; Tiwari et al. 2009),

101 and 20\% compared outcomes across different types of work (Aktas and Esin ; Carmen et al.

102 2003; Castro et al. 2005; Castro and Hunting 2013; Dey 2008; Esin et al. 2005; Fischer et al.

103 2003; French 2010; Gargy et al. 2011; Harari et al. 1997; Jildeh et al. 2014; Mohan et al.

104 2015; O'Donnell et al. 2005; Schlick et al. 2014). A roughly equal proportion of studies

105 examined each of the health outcome categories: 26\% for nutritional status (Ambadekar et al.

106 1999; Ansari et al. 2015; Banerjee et al. 2008; Beegle et al. 2009; Chandrashree 2014;

107 Cortez et al. 2007; Daga 2000; Duyar and Ozener 2005; Etiler et al. 2011; Gross et al. 1996;

108 Hawamdeh and Spencer 2002; Hawamdeh and Spencer 2003a; Hawamdeh and Spencer

109 2003b; Hawamdeh et al. 2001; Hincapie 2007; Kana et al. 2010; Mohan et al. 2015;

110 Nicolella et al. 2008; O'Donnell et al. 2005; Roggero et al. 2007), 28\% for injuries (Ahmed

111 and Ray 2014; Amiri et al. 2014; Ayelo et al. 2013; Baron 2005; Carmen et al. 2003; Castro

112 et al. 2005; Castro and Hunting 2013; Cuadra et al. 2007b; Dalal et al. 2016; Dey 2008; El-

113 Gilany et al. 2007; Fassa et al. 2005; Fischer et al. 2003; Graves et al. 2014; Javed et al.

2013; Jildeh et al. 2014; Khan et al. 2007; Pinzon-Rondon et al. 2009; Saha and Sadhu 
2014; Schlick et al. 2014; Tiwari et al. 2004; Vasconcelos et al. 2010), and 30\% for harmful exposures (Aktas and Esin ; Athanasiadou et al. 2008; Baig et al. 2005; Basema et al. 2003; Bose-O'Reilly et al. 2008; Cuadra et al. 2007b; Cuadra et al. 2009; Cuadra et al. 2006; Das et al. 2011; Elci et al. 2007; Esin et al. 2005; French 2010; Furman and Laleli 2000; Gargy et al. 2011; Harari et al. 1997; Junaid et al. 2017; Oviedo-Trespalacios et al. 2013; Saddik et al. 2005; Singhal et al. 2006; Sughis et al. 2012; Sughis et al. 2014; Tiwari 2013; Tiwari et al. 2009; Zaki et al. 1998). The remaining studies (Awan et al. 2010; Caglayan et al. 2010; Das et al. 2013; DM Satpathy 2005; Doocy et al. 2007; Gol 2016; Joshi et al. 1996; Laraqui et al. 2000; Miquilin Ide et al. 2015; Nuwayhid et al. 2005; Omokhodion and Omokhodion 2004; Zainab and Kadir) examined more than one of these three outcome categories (Table 1).

\section{Nutritional Outcomes}

Nutritional status was mostly assessed by height for age, weight for age, presence of anemia, and body mass index (BMI). Fourteen studies had a control group of non-working children (Ambadekar et al. 1999; Awan et al. 2010; Das et al. 2013; Doocy et al. 2007; Duyar and Ozener 2005; Etiler et al. 2011; Hawamdeh and Spencer 2002; Hawamdeh and Spencer 2003b; Hincapie 2007; Joshi et al. 1996; Laraqui et al. 2000; Miquilin Ide et al. 2015; Nicolella et al. 2008; O'Donnell et al. 2005; Omokhodion and Omokhodion 2004) and examined the relation between child work and nutrition. Only four studies had a longitudinal design (Beegle et al. 2009; Laraqui et al. 2000; Nicolella et al. 2008; O'Donnell et al. 2005). Generally, studies found associations between child labor and poorer nutritional status. On average, child workers had lower weight and height for age (Ambadekar et al. 1999; Chandrashree 2014; Cortez et al. 2007; Duyar and Ozener 2005; Gross et al. 1996; 
Hawamdeh and Spencer 2003a; Roggero et al. 2007), compared to non-working children or a reference population (commonly those of the United Kingdom or the National Center for Health Statistics in the United States). Packed cell volume was found to be below the threshold of anemia (35\%) in Jordanian working boys (Hawamdeh and Spencer 2003a; Hawamdeh et al. 2001), with working boys having lower values than their non-working siblings (Hawamdeh and Spencer 2002).

The relation between child work and nutrition may be non-linear; in a study from rural

Cambodia, there was an inverse U-shaped association between the numbers of hours of labor and nutritional status (Kana et al. 2010).This suggests that health status improves if the working hours of children is shorter than the turning point, which was around 18 hours/week. One study in rural Vietnam found that children engaged in paid work were heavier than their peers either working only for the household or not at all (O'Donnell et al. 2005). The association may also vary depending on the type of work; a study from Durg District in India showed that children engaged in sedentary work were significantly taller than children engaged in heavy work (Mohan et al. 2015). Few studies reported a relation between child labor and BMI (appendix 3).

The cross-sectional design, small sample size and lack of covariate adjustment in half of the studies included were the major limitations to the interpretation of these findings.

\section{Injuries}

Almost all studies investigated nonfatal injuries. One-half of studies described the prevalence or incidence of injury among working children (Amiri et al. 2014; Ayelo et al. 2013; Baron 2005;

Caglayan et al. 2010; Dalal et al. 2016; DM Satpathy 2005; El-Gilany et al. 2007; Javed et al. 2013; Khan et al. 2007; Miquilin Ide et al. 2015; Pinzon-Rondon et al. 2009; Saha and 
Sadhu 2014; Tiwari et al. 2004) and the other half compared injury rates among different types

\section{Harmful exposures} children showing a prevalence of work-related injuries 4-5 times higher than those working in the non-agricultural sector (Castro et al. 2005; Castro and Hunting 2013; Jildeh et al. 2014). Those working in manufacturing and domestic services had a higher prevalence of back pain (Fassa et al. 2005). A prospective study among child laborers in rural communities in Bangladesh (Dalal et al. 2016) showed that younger age ( $<10$ years) is associated with an increased incidence of injury-related illness. A retrospective study in Iran found that among construction workers, the accident rate among teenagers (15 to 19 years) was almost six times higher than that of young adults (20 to 24 years) (Amiri et al. 2014). Boys seems to sustain more severe injuries than girls (Ahmed and Ray 2014; Baron 2005; Fischer et al. 2003; Jildeh et al. 2014; Vasconcelos et al. 2010). As with nutritional status, injuries seem to increase steadily with the number of hours worked after a certain threshold of around 19 hours/week (Ahmed and Ray 2014; Amiri et al. 2014) (appendix 3). However, 26 of the 29 studies had a non-longitudinal design, limiting the interpretation of these results. 

diphenyl ethers (PBDEs), 2,5hexanedione, cosmetics and shampoo; environmental toxins (lipid hydroperoxide in serum); and organic and inorganic solvents.

Only five studies of the 28 studies with harmful exposures as outcomes (Baig et al. 2005;

Elci et al. 2007; Gol 2016; Oviedo-Trespalacios et al. 2013; Zaki et al. 1998) did not have a comparison group. The working environment of most working children was considered below the acceptable standards for proper arrangement of ventilation, light, garbage disposal, temperature, level of noise and minimal appropriate safety standards (Baig et al. 2005; Esin et

\section{al. 2005; Gol 2016; Oviedo-Trespalacios et al. 2013).}

Five studies (four in Nicaragua and one in Bangladesh) investigated child labor in waste disposal sites (Athanasiadou et al. 2008; Cuadra et al. 2007a; Cuadra et al. 2009; Cuadra et al. 2006; Gargy et al. 2011). Of those, two studies found that serum levels of PBDEs among 196 working children (Athanasiadou et al. 2008; Cuadra et al. 2007a) were 20-50 times the serum 197 level of non-working children. These serums concentrations among children working and living 198 at the waste disposal site were among the highest ever reported. Higher levels of several 199 polychlorinated biphenyl congeners were observed among the children who lived and worked at 200 a Managua-waste-disposal site (Cuadra et al. 2006). In addition, one study in the same site 201 (Cuadra et al. 2009) found that children working at the waste disposal site showed higher blood 202 levels of lead, mercury and cadmium, $28 \%$ having lead levels higher than $100 \mathrm{~g} / \mathrm{l}$, the level the 203 US Centers for Disease Control (CDC) considers as actionable. Finally, a study in Dhaka, 204 Bangladesh found that working in garbage dumping sites was also associated with DNA damage 205 (Gargy et al. 2011). Compared to a non-working control group, working children had a higher 
levels of protein carbonyl, a well-known marker of protein damage, and a longer tail moment, a commonly used marker of DNA damage.

Children working in agricultural, construction and gem polishing sectors had a lower Peak Expiratory Flow (PEFR) compared to non-working children (Das et al. 2011; Das et al. 2013; Joshi et al. 1996; Singhal et al. 2006). Child labor was also associated with lead and 211 mercury toxicity (Harari et al. 1997; Nuwayhid et al. 2005; Zaki et al. 1998). Children 212 working in automotive spray painting, mechanical repair, searching for gold-amalgam, and 213 furniture painting workshops who were exposed to solvents (e.g. mercury, lead) showed poorer 214 performance in various tests (choice reaction time test, hand-eye coordination tests, symbol-digit 215 test, spatial memory tests, matchbox test and the pencil tapping test) when compared to both 216 working non-exposed children and non-working children (Basema et al. 2003; Bose-O'Reilly et 217 al. 2008; Saddik et al. 2005). Exposed working children also complained significantly more 218 about excessive salivation and a metallic taste in the mouth(appendix 3) (Bose-O'Reilly et al. 219 2008).

DISCUSSION

This systematic review suggests that child labor in LMICs is negatively associated with 224 some aspects of nutritional status, and increased prevalence of injuries and harmful exposures. 225 Concerning harmful exposures, working children had high serum levels of many harmful 226 elements, such as PBDEs, which are known to be associated with thyroid hormone disruption, 227 memory impairment, impaired neurobehavioral development, iron deficiency, and impaired 228 hearing (Amler and Smith 2001; Calderón et al. 2001; Siddiqi et al. 2003). In addition, working 229 children exposed to solvents (e.g. mercury, lead) showed poorer performance in various memory 
230 tests. However, an overview of the extent of hazardous lead exposure in child laborers published 231 in 2005 concluded that the potential magnitude of the hazard of lead exposure in child laborers is 232 unclear (Ide and Parker 2005). Concerning nutritional status, working in non-sedentary sectors 233 (e.g. agricultural, construction) was associated with lower height and weight, but not with 234 differential BMI. This might be the result of child labor affecting height and weight in the same 235 direction and magnitude. A high prevalence of non-fatal injuries and musculoskeletal pain was 236 found in working children. The latter can lead to perceived thermodysregulation, hypervigilance 237 and hypersensitivity (Clinch and Eccleston 2009).

238 Our findings build on a recent review by (Shendell et al. 2016). That review focused on 239 lead and chemical exposure hazards, missed education, and health of street children who are 240 quite distinct from the general population of child workers. In addition, it only included 241 references available in the English language, and excluded many nutritional outcomes, a 242 potential long-term consequence of child labor.

243 Our first observation on the state of the science is the poor methodological quality of 244 most studies. For example, many papers reported odds ratios (OR) as measures of association, 245 even if the outcome frequency was common, which exaggerates the relative risk(Rothman et al. 246 2008). Sampling was sometimes done in a non-representative fashion and almost all studies 247 failed to report the frequency of missing data. In addition, only one third of studies having at 248 least one control (non-working children) group adjusted for potential confounders in their 249 analyses. The lack of adjustment for potential confounding factors added to the possibility that 250 frail children might be less likely to find work at baseline (i.e. reverse causality).This might tend 251 to underestimate the adverse effects of child labor observed, seriously limiting the causal 252 interpretation of associations reported in these studies. 
Secondly, there was no study conducted solely in China (China appears in one study

including all developing countries) and only five in Africa were included. This regional imbalance was also present in the (Shendell et al. 2016) review. This imbalance needs to be explored, since no restriction in language was applied. Articles in Spanish, Portuguese, French and Turkish were included in our review. Therefore, it does appear that many regions are severely understudied. One possible explanation for the paucity of reports from China might be that few Chinese journals are indexed in databases such as PUBMED, EMBASE and Scopus (Fan et al. 2008; Xia et al. 2008). Concerning Africa, one study has shown that Sub-Saharan Africa lags in scientific and technical publications due to lack of a congenial political and academic environment in some countries, shortage of trained personnel to pursue academic research due to heavy teaching loads and inadequate financial support (Atuahene 2011). However, our review covers 26 LMICs which is fairly comprehensive.

Third, there might also be a high likelihood of publication bias in this review. Only three studies reported non-significant associations between child labor and health outcomes among all studies having a non-working control group. Finally, other aspects of child labor were not captured in this review, particularly, children involved in illicit activities such as prostitution and drug trafficking, which may be considerably more hazardous.

With over 170 million children involved in child labor, the limited peer-reviewed work identified in LMICs is clearly an indication that more research with longitudinal quantitative measures on child labor and health outcomes is urgently needed. Current evidence comes mostly from cross-sectional studies that are vulnerable to reverse causality and unmeasured confounding. We lack data from many parts of the developing world, particularly in China and Africa. 
27

8

\section{Ethical Statement}

278 The manuscript has not been published previously (partly or in full), and no data have been

279 fabricated or manipulated to support our conclusions. Consent to submit has been received 280 explicitly from all co-authors.

282 Compliance with ethical standards

283 Funding: This study was founded by the Canadian Institutes of Health Research Operating Grant, 284 "Examining the impact of social policies on health equity" (ROH-115209), the Foundation Grant 285 "Development epidemiology: identifying evidence-based interventions for improving population 286 health and promoting health equity (FRN 148467), and the Canada Research Chairs program.

287 Ethical approval: All procedures performed in studies involving human participants were in 288 accordance with the ethical standards of the institutional and/or national research committee and 289 with the 1964 Helsinki declaration and its later amendments or comparable ethical standards. 


\section{REFERENCES:}

Ahmed S, Ray R (2014) Health consequences of child labour in Bangladesh Demographic Research 30:111-150

Aktas E, Esin MN Skin disease symptoms and related risk factors among young workers in high-risk jobs Contact Dermatitis 75:96-105

Ambadekar NN, Wahab SN, Zodpey SP, Khandait DW (1999) Effect of child labour on growth of children Public Health 113:303-306 doi:10.1016/s0033-3506(99)00185-7

Amiri M, Ardeshir A, Zarandi MHF (2014) Risk-based analysis of construction accidents in Iran during 2007-2011-meta analyze study Iranian Journal of Public Health 43:507-522

Amler RW, Smith L (2001) Achievements in children's environmental health. [US Department of Health and Human Services, Public Health Service], Agency for Toxic Substances and Disease Registry, Office of Children's Health,

Ansari H, Moghaddam AA, Mohammadi M, Peyvand M, Gorgij A, Sanavi FS (2015) Health Status and Life Situtation of Street Chidren in Zahedan, Southeast of Iran Health Scope 4

Athanasiadou M, Cuadra SN, Marsh G, Bergman A, Jakobsson K (2008) Polybrominated diphenyl ethers (PBDEs) and bioaccumulative hydroxylated PBDE metabolites in young humans from Managua, Nicaragua Environmental Health Perspectives 116:400-408 doi:10.1289/ehp.10713

Atuahene F (2011) Re-thinking the Missing Mission of Higher Education: An Anatomy of the Research Challenge of African Universities Journal of Asian and African Studies 46:321-341 doi:doi:10.1177/0021909611400017

Awan S, Nasrullah M, Cummings KJ (2010) Health hazards, injury problems, and workplace conditions of carpet-weaving children in three districts of Punjab, Pakistan International journal of occupational and environmental health 16:115-121

Ayelo AP, Aguemon B, Santos A, Gounongbe F, Fourn L, Fayomi B (2013) Health aspects of child labour in the crushing of granite in central Benin African Newsletter on Occupational Health and Safety 23:21-23

Baig LA, Shahida R, Mehwash Z (2005) Health and safety measures available for young labourers in the cottage industries of Karachi JCPSP, Journal of the College of Physicians and Surgeons Pakistan 15:7-10

Banerjee SR, Bharati P, Vasulu TS, Chakrabarty S, Banerjee P (2008) Whole time domestic child labor in metropolitan city of Kolkata Indian Pediatrics 45:579-582

Baron SL (2005) Injuries in child laborers in the informal sector in Mexico City, Mexico, 1997 Public Health Reports 120:598-600

Basema S, Iman N, Williamson A, Black D (2003) Evidence of neurotoxicity in working children in Lebanon NeuroToxicology 24:733-739

Beegle K, Dehejia R, Gatti R (2009) Why should we care about child labor? The education, labor market, and health consequences of child labor Journal of Human Resources 44:871-889

Blair SL (1992) Children's participation in household labor: Child socialization versus the need for household labor Journal of Youth and Adolescence 21:241-258

Boothe P (2016) Goal 8: Promote sustained, inclusive and sustainable economic growth, full and productive employment and decent work for all Keeping Track: Measuring Progress Toward the UN Sustainable Development Goals:52

Bose-O'Reilly S, Lettmeier B, Gothe RM, Beinhoff C, Siebert U, Drasch G (2008) Mercury as a serious health hazard for children in gold mining areas Environmental Research 107:89-97 doi:10.1016/j.envres.2008.01.009

Caglayan C, Hamzaoglu O, Yavuz Cl, Yuksel S (2010) Working conditions and health status of child workers: Cross-sectional study of the students at an apprenticeship school in Kocaeli Pediatrics International 52:6-12 doi:10.1111/j.1442-200X.2009.02881.x 
Calderón J et al. (2001) Exposure to Arsenic and Lead and Neuropsychological Development in Mexican Children Environmental Research 85:69-76 doi:http://dx.doi.org/10.1006/enrs.2000.4106

Carmen M, del M, Blanco V (2003) The labour conditions and health of working kids and adolescents in the agriculture sector Trabajo y salud en ninos, ninas y adolescentes trabajadores del sector agricola 11:5-20

Castro CL, Gormly S, Ritualo AR (2005) The SIMPOC Philippine survey of children 2001: A data source for analyzing occupational injuries to children Public Health Reports 120:631-641

Castro CL, Hunting K (2013) Measuring hazardous work and identifying risk factors for non-fatal injuries among children working in Philippine agriculture American Journal of Industrial Medicine 56:709-719 doi:10.1002/ajim.22185

Center TWPA (2017) Child labor. https://www.worldpolicycenter.org/topics/child-labor/policies. Accessed 2017-04-17 2017

Chandrashree L (2014) Nutritional and social constraints of child labourers: a study in Bhubaneswar city Asian Journal of Home Science 9:422-426

Cigno A, Rosati FC (2005) The economics of child labour. Oxford University Press on Demand,

Clinch J, Eccleston C (2009) Chronic musculoskeletal pain in children: assessment and management Rheumatology 48:466-474 doi:10.1093/rheumatology/kep001

Convention ILO (2005) C182-Worst Forms of Child Labour Convention, 1999 Public Health Reports 120:591-593

Cortez SAE, Barbieri MA, Saraiva M, Bettiol H, da S, A AM, Cardoso VC (2007) Does child labour affect final height? Occupational Medicine-Oxford 57:118-125 doi:10.1093/occmed/kql155

Council EaS (2016) Progress towards the Sustainable Development Goals.

Cuadra S, Athanasiadou M, Bergman A, Jakobsson K (2007a) Polybrominated diphenyl ethers in serum from children working at a waste disposal site in Nicaragua Epidemiology 18:S183-S183

Cuadra S, Axmon A, Hernandez D, Jimenez M, Albin M, Jakobsson K (2007b) Work related injuries in children working at a waste disposal site in Nicaragua Epidemiology 18:S186-S186

Cuadra S, Lundh T, Jakobsson K (2009) Exposure to Heavy Metals in Children Working at a Waste Disposal Site, and in Reference Children from Managua, Nicaragua Epidemiology 20:S95-S95

Cuadra SN, Linderholm L, Athanasiadou M, Jakobsson K (2006) Persistent organochlorine pollutants in children working at a waste-disposal site and in young females with high fish consumption in Managua, Nicaragua Ambio 35:109-116 doi:10.1579/0044-7447(2006)35[109:popicw]2.0.co;2

Daga AS (2000) Relative risk and prevalence of illness related to child labor in a rural block Indian Pediatrics 37:1359-1360

Dalal K, Rahman F, Gifford M, Rahman A (2016) The magnitude of injury problems among child labourers in a rural community of Bangladesh: Findings from an injury surveillance system International Health 8:73-76

Das B, Ghosh T, Gangopadhyay S (2011) Peak expiratory flow rate among child labourers in West Bengal, India Indian pediatrics 48:487-488

Das B, Ghosh T, Gangopadhyay S (2013) Child Work in Agriculture in West Bengal, India: Assessment of Musculoskeletal Disorders and Occupational Health Problems Journal of Occupational Health $55: 244-258$

Dey I (2008) Working environment and morbidities of child laborers in an urban slum of kolkata Indian journal of community medicine : official publication of Indian Association of Preventive \& Social Medicine 33:278-279

DM Satpathy TS (2005) Socio-clinical Profile of Rabies cases in Anti-Rabies Clinic, M.K.C.G. Medical College, Berhampur, Orissa Indian J Public Health 49:241-242

Doocy S, Crawford B, Boudreaux C, Wall E (2007) The risks and impacts of portering on the well-being of children in Nepal Journal of Tropical Pediatrics 53:165-170 
Duyar I, Ozener B (2005) Growth and nutritional status of male adolescent laborers in Ankara, Turkey American Journal of Physical Anthropology 128:693-698

El-Gilany AH, Khalil IAH, El-Wehady A (2007) Epidemiology and hazards of student labour in Mansoura, Egypt Eastern Mediterranean health journal = La revue de sante de la Mediterranee orientale = al-Majallah al-sihhiyah li-sharq al-mutawassit 13:347-363

Elci O, Yener G, Ucku R (2007) Working conditions and related neuropsychiatric problems among shoemakers in Turkey: Do child workers differ from others? Indian Journal of Occupational and Environmental Medicine 11:9-14

Esin MN, Bulduk S, Ince H (2005) Workrelated risks and health problems of working children in urban Istanbul, Turkey Journal of Occupational Health 47:431-436

Etiler N, Caglayan C, Cizmecioglu FM, Yavuz Cl, Hatun S, Hamzaoglu O (2011) Effect of labour on child body: the comparison of two studies in Izmit Turk Pediatri Arsivi-Turkish Archives of Pediatrics 46:111-117 doi:10.4274/tpa.46.56

Fan WY, Tong YY, Pan YL, Shang WL, Shen JY, Li W, Li L (2008) Traditional Chinese Medical Journals currently published in mainland China Journal of alternative and complementary medicine (New York, NY) 14:595-609 doi:10.1089/acm.2008.0009

Fassa AG, Facchini LA, Dall'Agnol MM, Christiani DC (2000) Child labor and health: problems and perspectives International Journal of Occupational and Environmental Health 6:55-62

Fassa AG, Facchini LA, Mor Dall'Agnol M, Christiani DC (2005) Child labor and musculoskeletal disorders: The pelotas (Brazil) epidemiological survey Public Health Reports 120:665-674

Fischer FM, Martins IS, Oliveira DC, Teixeira LR, do Rosario DLM, Cooper SP (2003) Occupational accidents among middle and high school students of the state of Sao Paulo, Brazil Revista de Saude Publica 37:351-356

French JL (2010) Children's Labor Market Involvement, Household Work, and Welfare: A Brazilian Case Study Journal of Business Ethics 92:63-78 doi:10.1007/s10551-009-0140-y

Furman A, Laleli M (2000) Semi-occupational exposure to lead: a case study of child and adolescent street vendors in Istanbul Environmental research 83:41-45

Gargy L, Tania R, Hasan AKMM, Dutta AK, Arif M, Howlader ZH (2011) Assessment of impact on health of children working in the garbage dumping site in Dhaka, Bangladesh Journal of Tropical Pediatrics 57:472-475

Genicot G (2005) Malnutrition and child labor The Scandinavian Journal of Economics 107:83-102

Gol I (2016) Evaluation of working conditions and perceptions of health status and the importance of health in child and young workers in the industrial site. [Turkish] TAF Preventive Medicine Bulletin 15:347-353

Graves JM, Ali MV, Gunn SE (2014) Occupational injuries among child labourers: Preliminary results from a study of the brick manufacturing industry in four countries 24th International Conference on Epidemiology in Occupational Health, EPICOH 2014: Challenges for Occupational Epidemiology in the 21st Century Chicago, IL United States Conference Start: 20140624 Conference End: 20140627 71:A54

Gross R, Landfried B, Herman S (1996) Height and weight as a reflection of the nutritional situation of school-aged children working and living in the streets of Jakarta Social Science and Medicine 43:453-458

Harari R, Forastiere F, Axelson O (1997) Unacceptable "occupational" exposure to toxic agents among children in Ecuador American Journal of Industrial Medicine 32:185-189

Hawamdeh H, Spencer N (2002) Growth of working boys in Jordan: A cross-sectional survey using nonworking male siblings as comparisons Child: Care, Health and Development 28:47-49

Hawamdeh $\mathrm{H}$, Spencer $\mathrm{N}$ (2003a) Effect of work related variables on growth among working boys in Jordan Journal of epidemiology and community health 57:154-158 
Hawamdeh H, Spencer N (2003b) The effects of work on the growth of Jordanian boys Child: Care, Health and Development 29:167-172

Hawamdeh H, Spencer N, Waterston T (2001) Work, family socioeconomic status, and growth among working boys in Jordan Archives of Disease in Childhood 84:311-314

Hincapie D (2007) Child labor and the nutritional status of Colombian children Desarrollo y Sociedad:63115

Ide LS, Parker DL (2005) Hazardous child labor: lead and neurocognitive development Public health reports (Washington, DC : 1974) 120:607-612

ILO (2011) Definition: What is meant by child labour? http://www.ilo.org/moscow/areas-of-work/childlabour/WCMS 249004/lang--en/index.htm. Accessed 2017-04-06 2017

International Labour Office ILO (2017) ILO Declaration on Fundamental Principles and Rights at Work. ILO. http://www.ilo.org/declaration/lang--en/index.htm. Accessed 2017-02-17 2017

Javed S, Shah N, Memon MY (2013) Occupational hazards, illness and injuries faced by child labourers JPMA The Journal of the Pakistan Medical Association 63:139-142

Jildeh C, Abdeen Z, Al Sabbah H, Papandreou C, Ghannam I, Weller N, Philalithis A (2014) Labor and related injuries among schoolchildren in Palestine: findings from the National Study of Palestinian Schoolchildren (HBSC-WBG2006) ISRN pediatrics 2014

Joshi SK, Sharma P, Sharma U, Sitaraman S, Pathak SS (1996) Peak expiratory flow rate of carpet weaving children Indian pediatrics 33:105-108

Junaid M, Malik RN, Pei DS (2017) Health hazards of child labor in the leather products and surgical instrument manufacturing industries of Sialkot, Pakistan Environmental Pollution 226:198-211

Kana M, Phoumin H, Seiichi F (2010) Does Child Labour Have a Negative Impact on Child Education and Health? A Case Study in Rural Cambodia Oxford Development Studies 38:357-382 doi:10.1080/13600818.2010.505682

Khan H, Hameed A, Afridi AK (2007) Study on Child labour in autombile workshops of Peshawar, Pakistan Eastern Mediterranean Health Journal 13:1497-1502

Laraqui CH, Caubet A, Laraqui O, Belamallem I, Harourate K, Curies JP, Verger C (2000) Child labour in the handicraft sector of Morocco: Causes and repercussions on health. [French] Sante Publique 12:31-43

Miquilin Ide O, Marin-Leon L, Luz VG, La-Rotta El, Correa Filho HR (2015) [Demographic, socioeconomic, and health profile of working and non-working Brazilian children and adolescents: an analysis of inequalities] Cad Saude Publica 31:1856-1870 doi:10.1590/0102-311x00142214

Mohan SM, Bharadwaj SK, Omre PK (2015) Physical and intellectual development of children (9-12 years) in child labour schools in relation to nutrition and labour with special reference to Durg district International Journal of Tropical Agriculture 33:1869-1874

Moher D, Liberati A, Tetzlaff J, Altman DG, Group P (2009) Preferred reporting items for systematic reviews and meta-analyses: the PRISMA statement PLoS med 6:e1000097

Nicolella AC, Kassouf AL, Barros ALMd (2008) O impacto do trabalho infantil no setor agrícola sobre a saúde Revista de Economia e Sociologia Rural 46:673-701

Nishijima M, Souza AP, Sarti FM (2015) Trends in child labor and the impact on health in adulthood in Brazil from 1998 to 2008 Cadernos de saude publica 31:1071-1083

Nuwayhid IA, Usta J, Makarem M, Khudr A, El-Zein A (2005) Health of children working in small urban industrial shops Occupational and Environmental Medicine 62:86-94

O'Donnell O, Rosati FC, Van Doorslaer E (2005) Health effects of child work: Evidence from rural Vietnam Journal of Population Economics 18:437-467

Office IL (2011) Children in hazardous work: what we know, what we need to do. International Labour Office, 
Omokhodion FO, Omokhodion SI (2004) Health status of working and non-working school children in Ibadan, Nigeria Annals of tropical paediatrics 24:175-178

Oviedo-Trespalacios O, Manjarrés R, Maestre-Meyer M, Peñabaena-Niebles R, Holgado D (2013) Study of Hazardous Work Conditions Prevalence in Child Labour: A survey of the Colombian Caribbean Region Social Science and Education 47

Parker DL (1997) Child labor: the impact of economic exploitation on the health and welfare of children Minnesota medicine 80:10-13, 52-55

Pinzon-Rondon AM, Koblinsky SA, Hofferth SL, Pinzon-Florez CE, Briceno L (2009) Work-related injuries among child street-laborers in Latin America: Prevalence and predictors Revista Panamericana de Salud Publica/Pan American Journal of Public Health 26:235-243

Roggero P, Mangiaterra V, Bustreo F, Rosati F (2007) The health impact of child labor in developing countries: evidence from cross-country data Am J Public Health 97:271-275 doi:10.2105/ajph.2005.066829

Rothman KJ, Greenland S, Lash TL (2008) Modern epidemiology. Lippincott Williams \& Wilkins,

Saddik B, Williamson A, Nuwayhid I, Black D (2005) The effects of solvent exposure on memory and motor dexterity in working children Public health reports:657-663

Saha A, Sadhu HG (2014) Occupational injury proneness in young workers: a survey in stone quarries J Occup Health 55:333-339

Schlick C, Joachin M, Briceno L, Moraga D, Radon K (2014) Occupational injuries among children and adolescents in Cusco Province: a cross-sectional study BMC public health 14:766

Shendell DG, Noomnual S, Chishti S, Sorensen Allacci M, Madrigano J (2016) Exposures Resulting in Safety and Health Concerns for Child Laborers in Less Developed Countries Journal of Environmental and Public Health 2016

Siddiqi MA, Laessig RH, Reed KD (2003) Polybrominated Diphenyl Ethers (PBDEs): New Pollutants-Old Diseases Clinical Medicine and Research 1:281-290

Singhal S, Singhal A, Singh PN, Agarwal DK, Gulati R (2006) Peak expiratory flow rate of children working in lock factories Indian journal of public health 50:47-48

Sughis M, Nawrot TS, Haufroid V, Nemery B (2012) Adverse Health Effects of Child Labor: High Exposure to Chromium and Oxidative DNA Damage in Children Manufacturing Surgical Instruments Environmental Health Perspectives 120:1469-1474 doi:10.1289/ehp.1104678

Sughis M, Nawrot TS, Riaz A, Ikram-Dar U, Mahmood A, Haufroid V, Nemery B (2014) Metal exposure in schoolchildren and working children. A urinary biomonitoring study from Lahore, Pakistan International journal of hygiene and environmental health 217:669-677

Tiwari RR (2013) Eyestrain in working children of footwear making units of Agra, India Indian Pediatrics 50:411-413

Tiwari RR, Saha A, Parikh JR (2009) Respiratory morbidities among working children of gem polishing industries, India Toxicology and Industrial Health 25:81-84

Tiwari RR, Saha A, Parikh JR, Saiyed HN (2004) Injuries and injury care among child labourers in gem polishing industries in Jaipur, India J Occup Health 46:216-219

Vasconcelos D, R BA, Santos JCV, Araujo RF, de S, Dantas RAA, Gurgel RQ (2010) Occupational injuries in children and adolescents in emergency services of Aracaju, Brazil Child Care Health and Development 36:369-374 doi:10.1111/j.1365-2214.2010.01078.x

Wells G, Shea B, O'connell D, Peterson J, Welch V, Losos M, Tugwell P (2011) The Newcastle-Ottawa Scale (NOS) for assessing the quality of nonrandomised studies in meta-analyses. Ottawa: Ottawa Hospital Research Institute; 2011. oxford. asp,

WorldBank (2016) Country Profiles. http://data.worldbank.org/data-catalog/country-profiles. 
Xia J, Wright J, Adams CE (2008) Five large Chinese biomedical bibliographic databases: accessibility and coverage Health information and libraries journal 25:55-61 doi:10.1111/j.14711842.2007.00734.x

Zainab S, Kadir M Nutritional status and physical abuse among the children involved in domestic labour in Karachi Pakistan: a cross-sectional survey JPMA - Journal of the Pakistan Medical Association 66:1243-1248

Zaki A, El Shazly M, Abdel Fattah M, El Said K, Curtale F (1998) Lead toxicity among working children and adolescent in Alexandria, Egypt Eastern Mediterranean health journal 4:520-529 